\section{Simultaneous Detection of} B-Cell Chronic Lymphocytic Leukemia and Colon Adenocarcinoma in the Same
Mesenteric Lymph Node

Aynı Mezenterik Lenf Bezinde B-Hücreli Kronik Lenfositik Lösemi ve Kolon Adenokanserinin Eş Zamanlı Saptanması

Keywords: Chronic lymphocytic leukemia, CLL, Colon adenocarcinoma

\author{
Ahmet Emre Eşkazan1, Selin Berk², Ferhat Özden³, \\ Sibel Erdamar ${ }^{3}$, Nükhet Tüzüner ${ }^{3}$, Teoman Soysal ${ }^{4}$ \\ ${ }^{1}$ Diyarbakır Training and Research Hospital, Department of Hematology, \\ Diyarbakir, Turkey \\ 2İstanbul University Cerrahpaşa Faculty of Medicine, Department of \\ Internal Medicine, İstanbul, Turkey \\ ${ }^{3}$ İstanbul University Cerrahpaşa Faculty of Medicine, Department of \\ Pathology, İstanbul, Turkey \\ 4İstanbul University Cerrahpaşa Faculty of Medicine, Department of \\ Internal Medicine, Division of Hematology, İstanbul, Turkey
}

Address for Correspondence: Ahmet Emre EŞKAZAN, M.D.,

Diyarbakır Training and Research Hospital, Department of Hematology, Diyarbakır, Turkey Phone: +90 5337227376 E-mail: emreeskazan@hotmail.com

Received/Geliş tarihi : November 06, 2012 Accepted/Kabul tarihi : November 07, 2012

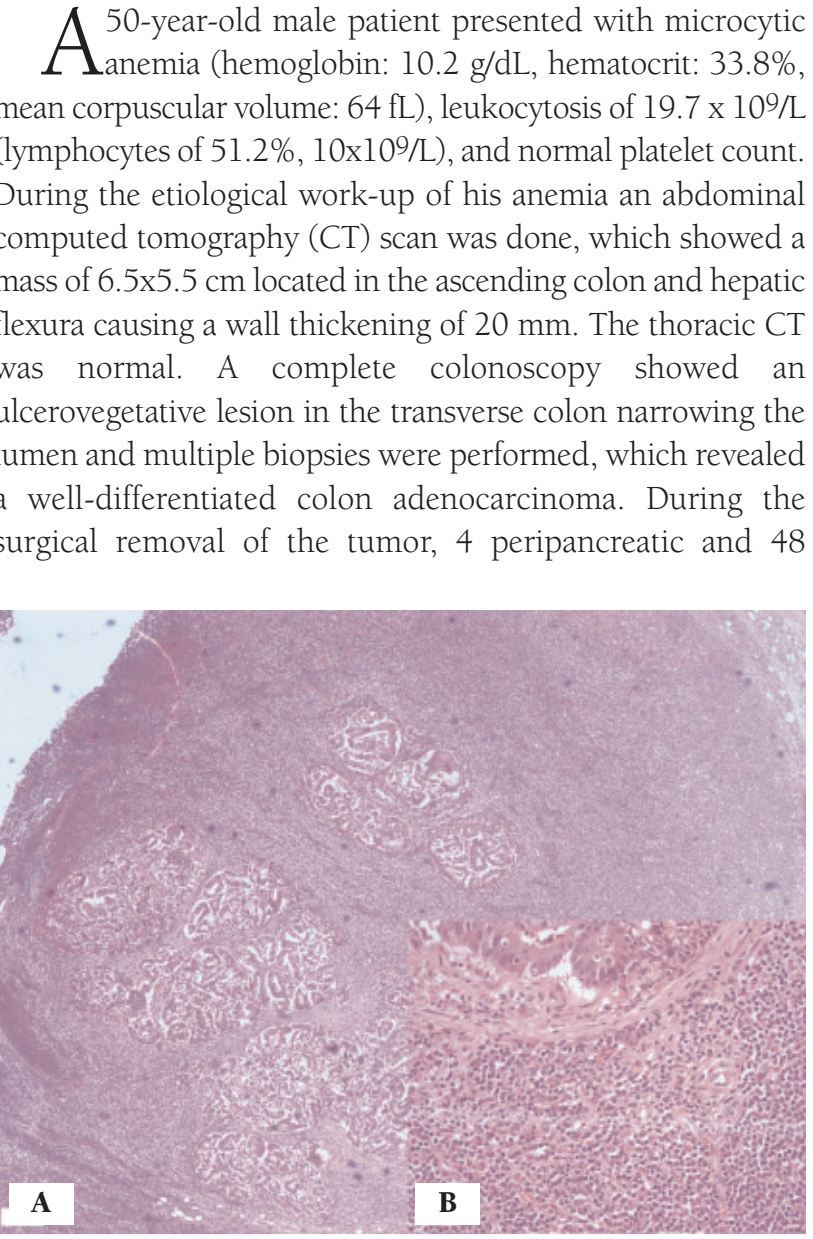

Figure 1: Adenocarcinoma metastasis and diffuse infiltration of small lymphocytes in the same mesenteric lymph node (A: hematoxylin and eosin, 40X; B: hematoxylin and eosin, $400 \times)$.

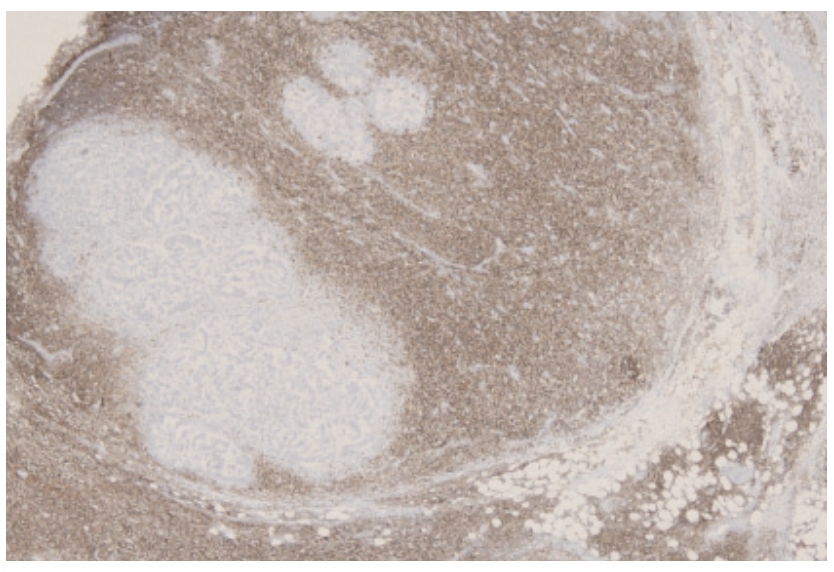

Figure 2: CD20 is positive in diffuse lymphoid infiltration, whereas it is negative in metastatic glands $(40 \times)$. 
mesenteric lymph nodes and the perilymphatic fat tissue were resected, which all had diffuse infiltration of atypical lymphocytes. In one mesenteric lymph node, both invasion of the colon adenocarcinoma and atypical lymphocytes were demonstrated (Figures $1 \mathrm{~A}$ and 1B). The atypical lymphocytes were immunohistochemically positive for CD20 (Figure 2), Bcl-2, CD23, and CD5 consistent with B-cell chronic lymphocytic leukemia/small lymphocytic lymphoma (B-CLL/SLL). After the patient was referred to the hematology department, flow cytometry was performed from the peripheral blood, which was also consistent with B-CLL/SLL. He had early-stage CLL and so we decided to monitor the disease; the patient was referred to the medical oncology department for the treatment of colon adenocarcinoma.

Patients with CLL have more than twice the risk of developing a second cancer, and this increased incidence is attributed to disease- or therapy-related immunosuppression [1]. The most common types of cancers developing in CLL patients are skin cancers, soft-tissue sarcoma, colorectal and lung carcinoma [2]. The incidental detection of CLL/SLL based on the histological evaluation of the lymph nodes resected for rectal adenocarcinoma is a rare entity $[3,4]$.

The synchronous diagnosis of B-CLL/SLL and colon adenocarcinoma in our case is most probably coincidental. However in the synchronous presentation of these two malignancies, an epidemiological association has been noted [5], and this synchronous relationship can also be explained in terms of the immunosuppression over a prolonged period of time.

\section{Conflict of Interest Statement}

All authors have no conflict of interest to declare.

\section{References}

1. Tsimberidou AM, Wen S, McLaughlin P, O'Brien S, Wierda WG, Lerner S, Strom S, Freireich EJ, Medeiros LJ, Kantarjian HM, Keating MJ. Other malignancies in chronic lymphocytic leukemia/small lymphocytic lymphoma. J Clin Oncol 2009;27:904-910.

2. Hisada M, Biggar RJ, Greene MH, Fraumeni JF Jr, Travis LB. Solid tumors after chronic lymphocytic leukemia. Blood 2001;98:1979-1981.

3. Dennis RJ, Alberts JC. The implications of an incidental chronic lymphocytic leukaemia in a resection specimen for colorectal adenocarcinoma. World J Surg Oncol. 2007;5:126.

4. Silvestris N, Zito FA, Fiore MG, Simone G, Tommasi S, Izzi G, Guarini A, Colucci G. Synchronous presentation of B-cell chronic lymphocytic leukemia/small-cell lymphoma and colon adenocarcinoma within the mesenteric lymph nodes and a single liver metastasis. J Clin Oncol 2011;29:e11-13.

5. Kyasa MJ, Hazlett L, Parrish RS, Schichman SA, Zent CS. Veterans with chronic lymphocytic leukemia/small lymphocytic lymphoma (CLL/SLL) have a markedly increased rate of second malignancy, which is the most common cause of death. Leuk Lymphoma 2004:45:507-513. 